\title{
Recognition and Appreciation and its Psychological Effect on Job Satisfaction and Performance in a Malaysia IT Company: Systematic Review
}

\author{
Norida Abdullah ${ }^{1}$ Olurotimi A. Shonubi ${ }^{2}$, Rahman Hashim ${ }^{3}$, Norhidayu Hamid ${ }^{4}$ \\ 1, Centre for Languages and Human Development, UniversitiTeknikal Malaysia Melaka, Hang Tuah Jaya, \\ 76100 Durian Tunggal, Malacca \\ 2,3,4, Institute of Technology Management and Entrepreneurship, UniversitiTeknikal Malaysia Melaka, Hang \\ Tuah Jaya, 76100 Durian Tunggal, Malacca
}

\begin{abstract}
There is a general assumption that every employee like to be recognized and appreciated, because they are everyday human innate need. Though, there has been extensive study on intrinsic motivational factors but still there still few studies on appreciation and recognition and how they can be well utilized in the organization to boost job satisfaction of employees. Thus, this paper aims to explore and examine previous literatures on employee intrinsic motivational factors and using those studies as background knowledge for this present study on employees' perception of recognition and appreciation and the influence it has on their job satisfaction, performance, productivity and commitment towards the organization goals and objectives. Recognition and appreciation which can also be refers to as intrinsic motivation are basic psychological process, therefore, becoming significance and inevitable to every human. However, this present study aims to utilize survey research method, vast of the constructs that will be used in this study will be operationalized using previously-validated and originally developed measures with little or no modifications where necessary to suit the present research context. Structural equation modeling using Amos will also be utilized to find the level of influence of recognition and as well as the level of appreciation towards TM employees' job satisfaction and performance.
\end{abstract}

Keywords: Recognition, Appreciation, Job satisfaction, Job Performance, Psychological Effect, IT employees

\section{INTRODUCTION}

"One of the laws of psychology positively articulates that if you want someone to repeat a behavior, you should positively recognize the behavior immediately" (Schultz, 2015). Exploration on employees' motivation, stated that today's workforce is more articulate about their needs and wants as well as desiring the best of everything; differing from competitive salaries, comfortable lifestyles, job security, job enhancement options, work-life balance (Limaye and Sharma, 2012). As human, our aspirations and need are endless and can never be satisfied, acknowledging this reality, this is why organizations need to have clear philosophies and strategies which supports workforces'advancement, as well as intrinsic ways of encouraging and engaging with the employees. While many organizations are attempting to make the big difference, some organizations have institutionalized robust practices and effective processes that go a long way in influencing employee perception. Based on (Matlala, 2011; Cokins 2009) these writers affirmed that "if organization use the wrong key performance indications, then the behavior, focal points and decisions of employees and their organization as a whole will never be well aligned with the course of the decision-making team".

However, studies on employee recognition pointed out that IT sector is said to be confronted mostly with constant mobility of their highly skilled personnel. As a result, there is need to prevent these negatives result and find out the factors that influence within the IT organization which may lead to job satisfaction and increased job performance among the IT employees. Mussie et al., (2013) articulated that one valuable outcome and reason for recognizing employees is the fact that people who feel treasured are more positive about themselves and their capacity to contribute, i.e., employee recognition can improve productivity and increase satisfaction (Mussie et al; 2013; Gostick \& Elton, 2007; Nelson, 2005; Daniels, 1999; Darling et al., 1997).An organization may use recognition as a standard measure to show employees that their contribution to the organization is acknowledged, and in so doing, influence their passion and job performance.

Matlala (2011) found that organization could improve and encourage the use of effective acknowledgement in the feedback process of the performance management system. The findings explained that recognition program may also influence the company to look at a more structured procedure to recognition that would allow the powerful culture it strives to get. Therefore, this present research will examine the 
psychological role of recognition and appreciation played in motivating employees and the moderating role of self-esteem. The study will explore which of these factors, recognition or appreciation, has a greater impact on employee job satisfaction and performance.It is unavoidable and important to identify that exceptionally satisfied and motivated employees are valuable assets for any business. The idea of staff satisfaction has great importance in the field of professional counselling. A huge amount of studies has been conducted on employees' satisfaction, though, many organizations use different tools to meet and motivate their employees (Tausif, 2012). Corresponding to Tausif (2012); Locke (1976), it was verified that over 3300 research articles have been created on this area, this demonstrates that study on employees' motivation is significant to organizations as long as they want to continue to be competitive and survive. The focal reason for the great interest in this field is the perception that work satisfaction influences employee productivity, absenteeism, turnover rate, and hence organization performance. Conforming to (Richard, 2006) the writer argued that organizations design and implement rewards packages to attract and retain employees. He also reveals that one of the great difficulty confronted by the organizations is to anticipate the behavior of their individual employee.

\section{LITERATURE REVIEW}

In order to understand recognition and appreciation and their psychological outcome on employee job satisfaction and performance. Systematic reviews of previous related past studies on intrinsic employees' motivational factors will be the guide to this present study in terms of constructing ideas and acquiring an overview and some level of conclusion on the issues related to IT employees' job satisfaction that may lead to increase job performance among IT employees in Melaka - Malaysia.

\section{RECOGNITIONAND APPRECIATION}

When it comes to employers and employees having innate satisfaction, recognition and appreciationare twoimportant tool for managers, businesses, Industrial counsellors and HR professionals in promoting worker motivation and organizational success.Study done by (Mussie et al; 2013; Allen and Helms, 2002) revealed that it is very important for employers to research regularly on expressing an appreciation to encouraged behavior of employees to reach strategic goals. Studies inMalaysia, Canada, Finland and North America confirmed that IT companies globally have been perceived as a high rate of employee turnover (Nurul et al, 2014; Tham et al., 2008; Westlund\& Hannon, 2008). Based on the exploration among Canadian employees, the study revealed what Canadian employees are looking for in a job, though getting good pay, job security and benefits are an important area of the package deal, but are not along with the set of what these employees were expecting. In order word, the study substantiated that the Canadian personnel create a higher worthy of on being treated with respect, doing interesting work, a feeling of fulfillment and good communication among co-workers (Sia, 2012; Finders \& Keepers - Recruiting and Retention Strategies, 2003).

Recognition shows confidence in workforces', and confident workforces are more gainful. Thus, it is critical to tell your workforces you have trust in their abilities and skills and share with others the extent you esteem your workers. Affirmingto (Paul, 2016) it was stressed that when employees' feel appreciated and esteemed for their commitments in the work environment, great results take after, including expanded worker commitment, less staff turnover, higher customer loyalty appraisals and the organization develops in its feeling of motivation. It was further revealed about the augmented interest on employee recognition programs in the working environment, to the point where more than 80 percent of organizations have some type of worker recognition, but at the same time work satisfaction has declined (Gallup, 2014; Globoforce, 2011; cited in Paul, 2016). Conversely, employee engagement remains low with just 30 percent of the workforce being effectively engaged. However, the study encouraged on the need to viably help workers feel genuinely esteemed and increased in value by their particular organization.

\section{PSYCHOLOGICAL EFFECTS OF RECOGNITION AND APPRECIATION}

As discussed by Ajang, (2010); Linder, (1998); Kreitner,(1995); Buford, Bedeian and Linder, (1995); Higgins, (1994;) these authors referred motivation to as "the psychological method that offers behavior purpose and direction, a predisposition to behave during a purposive manner to attain specific unmet desires, associate degree unhappy would like, and therefore the can to attain, severally. Other previous studies illuminate that when scientific discipline such as psychology originated as a profession, it had three goals: to spot genius, to heal the sick, and to assist people live better, happier lives (Maheshwari, 2012; Seligman \& Csikzentmihalyi, 2000; Seligman, 1998). Psychological motivations which might also be termed as Intrinsic motivation like workers having the chance to utilize their ability, having a way of challenge and accomplishment, receiving appreciation, positive recognition, and being treated during a caring and diplomatic manner (Akanbi, 2011). However, it wasaffirmed that this type of worker who is intrinsically motivated,as pictured by Akanbi, (2011) are committed to his work to the extent to that the work inherently contains tasks that rewarding to him or her. This author also suggested that for anemployee to be motivated in a worksituation, there must be a need, which 
the individual would have to perceivea possibility to understand a clear stage of satisfying through some reward. If the reward is intrinsic to the work, such need or motivation is intrinsic.

\section{THE RELATIONSHIP BETWEEN APPRECIATION, RECOGNITION AND PERFORMANCE}

A distinct difference between appreciation and recognition was made by Chapman and White,(2011). It was explicitly explained that appreciation can be given or done intentionally, for example, you give appreciation when you appreciate someone for whom they are, and so you can intentionally recognize a person's efforts when the situation calls for it. Psychological or intangible rewards (intrinsic) like recognition and appreciation plays a very important role in motivating staff and raising their performance. As opined by Fagley and Adler, (2012), "appreciation is genuinelyattached to spirituality through a method of mutual relation, and each seem to be key influences in psychological and physical well-being and effective performance within the worksetting, with every employee producing a definite impact and input". Tanner (2009), articulated that appreciation is basic,everyhumanneed appreciation,everyhumancraves for it, every humanrespond to it. Thus, that makes appreciation basic and significant to the success of any organizations.

Consequently, to empower anorganization, the people in the organization needs to be empowered too. To empower individuals, leaders ought to demonstrate appreciation in ways in which it will maximize the impact for every individual in the organization(Chapman and Paul, 2011). For recognition and appreciation to be effective, they need to be personal and delivered in person (McClelland, 1989; Frodi et al., 1985). Thus, theemployee with an honest performance can predict that their vital contributions are going to be completed and valued by the organization management (Bowen, 2000). Consecutively, recognition and appreciation includes a strong-willed and positive influence on worker performance.

\section{INTRINSIC REWARD}

Rafique et al., (2014) states that characteristically organizations focus a lot of on extrinsic rewards however intrinsic rewards were conjointly important in worker motivation. Appreciation and recognition are intrinsic rewards that encourage workers and improve their performance. As presented by (Andrew, 2004) employee's commitment depends on the rewards and recognition. According to (Robinand Robert, 2014)their study on "Intrinsic Motivations of Public Sector Employees: Evidence for Germany". The study found that performance of workers within the public sector depends way more on intrinsic motivations rather than of extrinsic. Anne, (2014), affirmatively revealed that intrinsically motivatedemployeesare more valuable to any organizations, since motivation results in performance. Thus, intrinsic motivation is part of the motivationconcept, and refers to performing a task for itself, in order to experience job satisfaction.

\section{MULTI GENERATION}

The organization today is very unique because of its workforces' diversity. As stated by Tay, (2011) he highlighted on the expectations of work attitudes and behaviors of characters from each generational group may be influenced by their significant life events, culture, and even their five senses. Ignoring these generational differences in the workplace could undoubtedly lead to less productive and competitive activities if the diverse expectations and perceptions of their employees and managers are not acknowledged and managed (Hai, 2013). It was further express that the way different employees perceive their places of work significantly impacts on their loyalty to their companies. Assenting to (Smith, 2010), there is always different of views, values, attitudes, motivations and life experiences among the 20s, 40s and 60s workers in anorganization. Study by (CHAN, 2014; Annastiina, 2012), on managing multigenerational workforce revealed that there are coexisting more generations than ever before at the workplace, and this has room to an inevitable multigenerational clashes. One key fact to note is that managing people with different personal, educational and professional backgrounds is rather difficult. Each generation has different values, working styles, expectations and attitudes. Therefore, it is fundamental for managers to pay attention to generational metamorphoses. As a result, they might get a functional, more interactive work community with a supportive atmosphere and a flat organizational structure (McCrindle and Wolfinger 2009; Whitacre 2007). However, the employers need to acknowledge not only the problems and pressures of mixed generations but also to see the opportunities, which come with the diversified workforce.

\section{DISCUSSION}

A systematic review of the literature was conducted utilizing keywords such as "recognition, "appreciation", 'information technology", "job satisfaction", "job performance" "psychological affect", "intrinsic motivation" and "employee engagement". Databases utilized included Google Scholar, Digital Dissertations, and ProQuest Direct. The search lead to in various refereed articles, books, and on-line resources. As sources were reviewed, additional citations were found and explored. The paper through different search 
engine as it methodology has systematically review the psychological effects of recognition and appreciation on employees' job satisfaction and job performance.

\section{CONCLUSION}

The present study intends to explore and examine employees' perception on recognition and appreciation and also to establish the best approaches preferred by the employees working in TM Melaka Malaysian organizations. This study expected to that the present study results can provide guidelines in developing an appropriate reward and recognition system forinformation technology organizations in general and literatures for future researchers most especially on employee's intrinsic motivational factors.

\section{ACKNOWLEDGMENT}

The authors would like to express sincere appreciation to C-TED and Sicomm Group and UniversitiTeknikal Malaysia Melaka (UTeM - Zamalah Scheme) for their financial support.

\section{REFERENCES}

[1] Abdullah, M.\&Afif. H. (2013). Relationship between Job Satisfaction and Turnover Intention: An Empirical Study on the IT Firms in Palestine; Interdisciplinary Journal of Research in Business Vol. 2, Issue. 8, (pp.67- 83).

[2] Ajila, C.O. (1997). Job Motivation and Attitude to Work as Correlates of Productivity among Workers in Manufacturing Companies in Lagos State. Nigeria. Unpublished Ph.D. Thesis submitted to the Department of Psychology O.A.U Ile-Ife Osun State, Nigeria.

[3] Allen R. \& Helms M. (2002). "Employee perceptions of relationships between strategy rewards and organizational performance", Journal of Business Strategies, Vol. 19, No. 2, pp. 115-139.

[4] Andrew, D \& Kent, R. (2007). The impact of perceived leadership behaviors on satisfaction, commitment, and motivation: An expansion of the multidimensional model of leadership ', International Journal of Coaching Science, 1(1), p 35-56.

[5] Andrew, D. P. S. \& Kent, A. (2004). The Impact of Perceived Leadership Behaviors on Satisfaction, Commitment, and Motivation: An Expansion of the Multidimensional Model of Leadership. International Journal of Coaching Science, 1 (1), pp. 37-58.

[6] Aniruddha, L. \&Ralsi, S. (2012).Rewards and Recognition: Make a difference to the talent in your organization. Edenred (India) Private Limited \& Great Place to Work Institute, India.

[7] Annastiina, R. (2012). Managing Multigenerational Workforce - How to bridge the generation gaps? Bachelor's Thesis JAMK University of Applied Sciences.

[8] Anne, J. (2014). Intrinsic Motivation in the Context of Low-Skilled Work: The Influence of Intrinsic Job Quality and Demands-Abilities Fit. Master Thesis in Human Resources Studies Submitted to Tilburg University.

[9] Asif, S; Hassan, G; \&Ramzan,M. (2013). Impact of Motivation on Employee Turnover in Telecom Sector of Pakistan, Journal of Business Studies Quarterly 2013, Volume 5, Number 1.

[10] Atif, R. (2014). A Study of the Factors Determining Motivational Level of Employees Working in Public Sector of Bahawalpur, International Journal of Human Resource Studies 2014, Vol. 4, No. 3.

[11] Bowen, B.B, (2000). Recognizing and rewarding employees, McGraw-Hill.

[12] Buford, J. A., Bedeian, A.G., \& Lindner, J. R. (1995). Management in extension. 3rd ed. Columbus, Ohio: Ohio State University Extension.

[13] Chan, S.Y. (2014). Generation Differences in Workplace Values and Strategies to Minimize the Conflict: A Case Study of Gano Excel Industries. A project paper submitted to the College of Law, Government and International Studies.

[14] Chapman, G. \& White, P. (2011), The 5 Languages of Appreciation in the Workplace, Northfield Press, Chicago, IL.

[15] Cokins, G. (2009). Performance management: Integrating strategy, execution, methodologies, risk and analytics. New Jersey: Wiley.

[16] Daniels A. (1999). Bringing out the Best in People: How to Apply the Astonishing Power of Positive Reinforcement (2nd ed.), New York: McGraw-Hill.

[17] Darling K., Arm J. \& Gatlin, R. (1997). "How to effectively reward employees", Industrial Management, Vol. 39, No. 4, pp. 1-4.

[18] Norzaidi, M.D; Anis, M. A. N;Fai'za, N; 'Ashikin, I; \&Intan, S. M. (2013). Determining Retention Factors Influencing Executives to Remain in Malaysian Organization, Journal of Applied Sciences Research, 9(9): 5502-5511, 2013. 
[19] Lumley, E. J; Coetzee, M; Tladinyane,R. \&Ferreira, N. (2011). Exploring the job satisfaction and organizational commitment of employees in the information technology environment, Southern African Business Review Volume 15 Number 1.

[20] Fagley, N. S., \& Adler, M. G. (2012). Appreciation: A spiritual path to finding value and meaning in the workplace. Journal of Management, Spirituality, and Religion, 9:2, 167-187.

[21] Frodi, A., Bridges, L., \&Grolnick, W. S. (1985). Correlates of mastery-related behavior: A short-term longitudinal study of infants in their second year. Child Development, 56, 1291-1298.

[22] Gallup (2014), Survey Findings: Employee Engagement, available at: www.gallup.com (Accessed $10^{\text {th }}$ May, 2016).

[23] Globoforce (2011), "SHRM survey findings: employee recognition programs", (Accessed 10 ${ }^{\text {th }}$ May, 2016).

[24] Gostick A. and Elton C. (2007). The Daily Carrot Principle: 365 Ways to Enhance Your Career and Life, New York: Simon \& Schuster.

[25] Herzberg, F. (1968). One more time: How do you motivate employees? Harvard Business Review 53.

[26] Higgins, J. M. (1994). The management challenge. 2nd ed. New York: Macmillan.

[27] Jordan, S.\& Christopher, K. (2012). I'm Leaving the IT Field: The Impact of Stress, Job Insecurity, and Burnout on IT Professionals. International Journal of Information and Communication Technology Research Volume 2 No. 1.

[28] Kreitner, R. (1995). Management. 6th ed. Boston: Houghton Mifflin.

[29] Lawler, E. E. (2003). Treat people right. San Francisco: Jossey-Bass Inc. McGraw-Hill Irwin. Mumford, M.D. (2000). Managing Creative People: Strategies and Tactics for Innovation, Human Resource Management Review, Vol.10, No.3, pp.313-351.

[30] Lindner, J. R. (1998). Understanding employee motivation. Journal of Extension 36 (3):1-8. Available: http://www.joe.org/joe/1998june/rb3.html (Accessed 10 ${ }^{\text {th }}$ May, 2016).

[31] Locke, E. A. (1976). The nature and causes of job satisfaction. In M.D. Dunnette (Ed.), Handbook of industrial and organizational psychology (pp.1297-1349). Chicago: Rand McNally.

[32] Mcclelland, D. (1989) Human Motivation, Madrid: Narcea, S.A. de Ediciones.

[33] McCrindle, M. \&Wolfinger, E. (2009). ABC of XYZ: understanding the global generations. Sydney: UNSW Press.

[34] Tausif, M. (2012). Relationship between Intrinsic Rewards and Job Satisfaction: A Comparative Study of Public and Private Organization. International Journal of Research in Commerce, IT \& Management, Vol. 2, No. 6.

[35] Mussie, T. T; Kathryn, J. R; \&, Abel, B. E. (2013). The Effects of Employee Recognition, Pay, and Benefits on Job Satisfaction: Cross Country Evidence, Journal of Business and Economics, Volume 4, No. 1, pp. 1-12.

[36] Nelson, B. (2005). 1001 Ways to Reward Employees (2nd ed.), New York: Workman Publishing.

[37] Nghi, T.\&Yecenia, R.O. (2007). Rewarding and Recognizing Employees: How IT Professionals in Sweden and in Finland are Motivated and Prefer to be rewarded. Blekinge Institute of Technology, Ronneby, Sweden Master Thesis in Business Administration.

[38] Nurul, E. A;Norzanah, M. N.\&Roshidi, H. (2014). Examining the Mediating Effect of Employee Engagement on the Relationship between Talent Management Practices and Employee Retention in the Information and Technology (IT) Organizations in Malaysia, Journal of Human Resources Management and Labor Studies, Vol. 2, No. 2, pp. 227-242.

[39] Paul, W. (2016). "Appreciation at Work training and the Motivating by Appreciation Inventory: development and validity”, Strategic HR Review, Vol. 15, 1 pp. 20 - 24.

[40] Peter, E. A. (2011). "Assessing the role of work Motivation on Employee Performance", C - Level Thesis Umeå School of Business and Economics.

[41] Reena, A.\&Shakil,M. A. (2009). The Impact of Reward and Recognition Programs on Employee's Motivation and Satisfaction: An Empirical Study, International Review of Business Research Papers Vol. 5 No. 4 Pp.270-279.

[42] Richard, I. H. (2006), "Compensation Management in a Knowledge Based World". (10th Edition) Pearson Education Inc. pp. 14-15.

[43] Robert, D.\& Robin, Z. (2014). Intrinsic Motivations of Public Sector Employees: Evidence for Germany. IZA Discussion Paper No. 8239.

[44] Sia, J. Y. (2012). A Survey of Factors Influencing Employee Engagement, MBA Thesis - UniversitiSains Malaysia.

[45] Tanner, O. C. (2009). Milestone Appreciation: A Powerful Tool for Engaging Employees. O.C. Tanner Company White Paper 
[46] Tay, A. (2013). Managing generational diversity at the workplace: expectations and perceptions of different generations of employees.African Journal of Business Management Vol. 5(2), pp. 249-255.

[47] Tham, G.Z.C., Pee, L.G., Kankanhalli, A., \& Tan, G.W. (2008). Turnover in information systems development projects: Managing forgetting. Pacific Asia Conference on Information Systems, Suzhou, China.

Westlund, S. G., \& Hannon J. C. (2008). Retaining Talent: Assessing Job Satisfaction Facets Most Significantly Related to Software Developer Turnover Intentions. Journal of Information Technology Management. Vol. XIX (4).

[48] Whitacre, T. (2007). Managing a Multigenerational Workforce. Quality Progress Dec 2007, Vol.40, Issue 12, 67-67.

[49] Yow, H. C. (2013). 'How different is different: a study of the workforce generation differences in relation to employee loyalty within the call center industry in Malaysia', DBA thesis, Southern Cross University, Lismore, NSW.

\section{Literature Summary Table}

\section{Appendix 1}

\begin{tabular}{|c|c|c|c|c|}
\hline Study & Purpose & Sector/Location & $\begin{array}{l}\text { Factors/Sampl } \\
\text { e Size }\end{array}$ & Relevant Findings \\
\hline $\begin{array}{l}\text { "Employee Retention: } \\
\text { A Review of Literature, } \\
\text { IOSR Journal of } \\
\text { Business and } \\
\text { Management Volume } \\
\text { 14, Issue } 2 \text { (Nov. - Dec. } \\
\text { 2013), PP 08-16. } \\
\text { BidishaLahkar Das, } \\
\text { Dr. MukuleshBaruah } \\
\text { (2013)". }\end{array}$ & $\begin{array}{l}\text { Analysis of } \\
\text { variousexisti } \\
\text { ng literature } \\
\text { and research } \\
\text { work on } \\
\text { employee } \\
\text { retention and } \\
\text { the factors } \\
\text { affecting } \\
\text { employee } \\
\text { retention and } \\
\text { job } \\
\text { satisfaction } \\
\text { among the } \\
\text { employees }\end{array}$ & Organization/India & $\begin{array}{l}\text { Employee } \\
\text { Retention, Job } \\
\text { Satisfaction, } \\
\text { Employee } \\
\text { Turnover }\end{array}$ & $\begin{array}{l}\text { HR professionals } \\
\text { should incorporate } \\
\text { these factors: } \\
\text { compensation } \\
\text { practices, leadership } \\
\text { and supervision, } \\
\text { career planning and } \\
\text { development, } \\
\text { alternative work } \\
\text { schedule, working } \\
\text { conditions, flexible } \\
\text { working hours in } \\
\text { their retention } \\
\text { program. }\end{array}$ \\
\hline $\begin{array}{l}\text { “A Survey of Factors } \\
\text { Influencing Employee } \\
\text { Engagement. SiaJoo } \\
\text { Yee (2012)”. }\end{array}$ & $\begin{array}{l}\text { To find out } \\
\text { the factors } \\
\text { that actually } \\
\text { drive } \\
\text { employees to } \\
\text { perform their } \\
\text { best. }\end{array}$ & $\begin{array}{l}\text { Manufacturing/Malay } \\
\text { sia }\end{array}$ & $\begin{array}{l}\text { Involvement } \\
\text { and } \\
\text { Participation, } \\
\text { Internal } \\
\text { Communicatio } \\
n, \\
\text { Recognitions } \\
\text { and Rewards, } \\
\text { Work-Life } \\
\text { Balance, } \\
\text { Employee } \\
\text { Engagement }\end{array}$ & $\begin{array}{l}\text { When an } \\
\text { organization or a } \\
\text { supervisor rewards } \\
\text { or recognizes an } \\
\text { employee or team, } \\
\text { they are connecting } \\
\text { in a powerful way on } \\
\text { activities and } \\
\text { accomplishments the } \\
\text { organization values. }\end{array}$ \\
\hline $\begin{array}{l}\text { "Relationship Between } \\
\text { Job Satisfaction and } \\
\text { Turnover Intention: An } \\
\text { Empirical Study on the } \\
\text { IT Firms in Palestine, } \\
\text { Interdisciplinary } \\
\text { Journal of Research in } \\
\text { Business Vol. 2, Issue. } \\
\text { 8, (pp.67-83). } \\
\text { Abdullah Murrar\&Afif } \\
\text { Hamad (2013)". }\end{array}$ & $\begin{array}{l}\text { To further } \\
\text { explore on } \\
\text { relationship } \\
\text { between job } \\
\text { satisfaction } \\
\text { and turnover } \\
\text { intention }\end{array}$ & IT Firms/Palestine & $\begin{array}{l}\text { Turnover } \\
\text { Intention, Job } \\
\text { Satisfaction, } \\
\text { Palestinian IT } \\
\text { Firms, } \\
\text { Palestinian IT } \\
\text { Employees. } \\
(150)\end{array}$ & $\begin{array}{l}\text { The findings show } \\
\text { job security, work } \\
\text { conditions, pay and } \\
\text { benefits, work } \\
\text { nature, coworkers, } \\
\text { career advancement, } \\
\text { supervision and } \\
\text { management were all } \\
\text { significantly } \\
\text { correlated with } \\
\text { overall job } \\
\text { satisfaction. Only job }\end{array}$ \\
\hline
\end{tabular}




\begin{tabular}{|c|c|c|c|c|}
\hline & & & & $\begin{array}{l}\text { security, pay, and } \\
\text { coworkers were able } \\
\text { to substantiallyeffect } \\
\text { turnover intention. }\end{array}$ \\
\hline $\begin{array}{l}\text { "Rewards and } \\
\text { Recognition: Make a } \\
\text { difference to the talent } \\
\text { in your organization. } \\
\text { AniruddhaLimaye \&Ral } \\
\text { si Sharma Great Place } \\
\text { to Work White Paper } \\
\text { Report". }\end{array}$ & $\begin{array}{l}\text { Sharing our } \\
\text { understandin } \\
g \text { of effective } \\
\text { and } \\
\text { innovative } \\
\text { rewards \& } \\
\text { recognition } \\
\text { practices }\end{array}$ & Organization/India & $\begin{array}{l}\text { Rewards and } \\
\text { Recognition }\end{array}$ & $\begin{array}{l}\text { Effective rewards } \\
\text { and recognition } \\
\text { practices need to } \\
\text { imitateanorganizatio } \\
n \text { 's culture (basic } \\
\text { values \& beliefs) and } \\
\text { combine well with } \\
\text { the nature of its } \\
\text { business, strategy } \\
\text { and goals. }\end{array}$ \\
\hline $\begin{array}{l}\text { "The Effects of } \\
\text { Employee Recognition, } \\
\text { Pay, and Benefits on } \\
\text { Job Satisfaction: Cross } \\
\text { Country Evidence, } \\
\text { Journal of Business } \\
\text { and Economics, } \\
\text { Volume 4, No. 1, pp. 1- } \\
\text { 12. Mussie T. } \\
\text { Tessemal, Kathryn J. } \\
\text { Ready, Abel B. Embaye } \\
\text { (2013)". }\end{array}$ & $\begin{array}{l}\text { assess the } \\
\text { relative } \\
\text { impact of } \\
\text { recognition, } \\
\text { pay, and } \\
\text { benefits on } \\
\text { job } \\
\text { satisfaction } \\
\text { on job } \\
\text { satisfaction }\end{array}$ & University/USA & $\begin{array}{l}\text { HR practices; } \\
\text { employee } \\
\text { recognition; } \\
\text { pay; benefits; } \\
\text { job } \\
\text { satisfaction; } \\
\text { culture; } \\
\text { Vietnam; } \\
\text { Malaysia; } \\
\text { USA (USA- } \\
\text { 457; Vietnam } \\
\text {-391; } \\
\text { Malaysia - } \\
\text { 347) }\end{array}$ & $\begin{array}{l}\text { Participants across } \\
\text { all three countries } \\
\text { are not only satisfied } \\
\text { at work and } \\
\text { motivated by } \\
\text { monetary rewards } \\
\text { such as pay and } \\
\text { benefits packages, } \\
\text { but are also } \\
\text { motivated by } \\
\text { nonmonetary } \\
\text { rewards such as } \\
\text { recognition, is apart } \\
\text { often overlooked by } \\
\text { superiors }\end{array}$ \\
\hline $\begin{array}{l}\text { "Determining } \\
\text { Retention Factors } \\
\text { Influencing Executives } \\
\text { to Remain in Malaysian } \\
\text { Organization Journal } \\
\text { of Applied Sciences } \\
\text { Research, 9(9): 5502- } \\
5511, \text { Dr } \\
\text { NorzaidiMohdDaud, } \\
\text { 2Anis Mohd Abdul } \\
\text { Nassir, 3Fai'za } \\
\text { Nurul 'AshikinIzany, Dr } \\
\text { Intan } \\
\text { Salwani Mohamed } \\
\text { (2013)". }\end{array}$ & $\begin{array}{l}\text { To determine } \\
\text { retention } \\
\text { factors } \\
\text { influencing } \\
\text { executives to } \\
\text { remain in } \\
\text { Malaysian } \\
\text { organization. }\end{array}$ & $\begin{array}{l}\text { Service } \\
\text { Industry/Malaysia }\end{array}$ & $\begin{array}{l}\text { Retention } \\
\text { factors, young } \\
\text { executive, } \\
\text { service } \\
\text { industry, } \\
\text { Malaysia } \\
(471)\end{array}$ & $\begin{array}{l}\text { It is imperative for } \\
\text { the organization to } \\
\text { embrace a stable } \\
\text { workforce in order to } \\
\text { build a significant } \\
\text { competitive } \\
\text { advantage against } \\
\text { the competitors. }\end{array}$ \\
\hline $\begin{array}{l}\text { "Appreciation at Work } \\
\text { training and the } \\
\text { Motivating by } \\
\text { Appreciation } \\
\text { Inventory: development } \\
\text { and validity", } \\
\text { Strategic HR Review, } \\
\text { Vol. } 15 \text { Iss } 1 \text { pp. } 20 \text { - } \\
24 . \text { Paul White, } \\
(2016) \text { ". }\end{array}$ & $\begin{array}{l}\text { This paper } \\
\text { aims to } \\
\text { present the } \\
\text { process, } \\
\text { progress and } \\
\text { validity of } \\
\text { the } \\
\text { Motivating } \\
\text { By } \\
\text { Appreciation } \\
\text { Inventory } \\
\text { and the } \\
\text { Appreciation } \\
\text { at Work } \\
\text { training. }\end{array}$ & Organization/USA & $\begin{array}{l}\text { Employee } \\
\text { engagement, } \\
\text { Appreciation, } \\
\text { Languages of } \\
\text { appreciation, } \\
\text { Recognition, } \\
\text { Employee } \\
\text { recognition }\end{array}$ & $\begin{array}{l}\text { When individuals } \\
\text { feel appreciated and } \\
\text { valued for their } \\
\text { influences in the } \\
\text { workplace, good } \\
\text { results follow, } \\
\text { including increased } \\
\text { employee } \\
\text { engagement, less } \\
\text { staff turnover, higher } \\
\text { customer satisfaction } \\
\text { ratings and the } \\
\text { organization grows } \\
\text { in its sense of } \\
\text { purpose }\end{array}$ \\
\hline
\end{tabular}




\begin{tabular}{|c|c|c|c|c|}
\hline $\begin{array}{l}\text { "Rewarding and } \\
\text { Recognizing } \\
\text { Employees: How IT } \\
\text { Professionals in } \\
\text { Sweden and in Finland } \\
\text { are Motivated and } \\
\text { Prefer to be Rewarded. } \\
\text { Nghi Tran \&Yecenia } \\
\text { Rivera Ortiz(2007)". }\end{array}$ & $\begin{array}{l}\text { To } \\
\text { investigate } \\
\text { through an } \\
\text { empirical and IT } \\
\text { and study in } \\
\text { theoretical } \\
\text { how are } \\
\text { professionals } \\
\text { in Sweden } \\
\text { and Finland are } \\
\text { motivated } \\
\text { and how they } \\
\text { prefer to be } \\
\text { rewarded } \\
\text { and recognized. }\end{array}$ & IT/Sweden \& Finland & $\begin{array}{l}\text { Information } \\
\text { technology, } \\
\text { motivation, } \\
\text { rewards and } \\
\text { recognition } \\
(284) \text {. }\end{array}$ & $\begin{array}{l}\text { Management in the } \\
\text { IT-industries to } \\
\text { dedicate more time } \\
\text { and interest to their } \\
\text { employee's } \\
\text { individual needs and } \\
\text { to improve } \\
\text { motivation, } \\
\text { recognition and } \\
\text { rewards systems. }\end{array}$ \\
\hline $\begin{array}{l}\text { "Impact of Motivation } \\
\text { on Employee Turnover } \\
\text { in Banking Sector of } \\
\text { Pakistan Journal of } \\
\text { Business Studies } \\
\text { Quarterly } \\
\text { 2013, Volume 5, } \\
\text { Number 1, Asif Sajjad, } \\
\text { Hassan Ghazanfar, Dr. } \\
\text { M Ramzan (2013)". }\end{array}$ & $\begin{array}{l}\text { Investigated } \\
\text { the impact of } \\
\text { motivation } \\
\text { on employee } \\
\text { turnover in } \\
\text { Telecom } \\
\text { sector of } \\
\text { Pakistan }\end{array}$ & Banking/Pakistan & $\begin{array}{l}\text { Motivation, } \\
\text { Turnover }\end{array}$ & $\begin{array}{l}\text { Increase in } \\
\text { motivation would } \\
\text { reduce the value of } \\
\text { employee turnover in } \\
\text { banking sector. }\end{array}$ \\
\hline $\begin{array}{l}\text { "Exploring the job } \\
\text { satisfaction and } \\
\text { organizational } \\
\text { commitment of } \\
\text { employees in the } \\
\text { information technology } \\
\text { environment, Southern } \\
\text { African Business } \\
\text { Review Volume } 15 \\
\text { Number 1. E.J. Lumley, } \\
\text { M. Coetzee, R. } \\
\text { Tladinyane\& } \\
\text { N. Ferreira } \\
\text { Department of } \\
\text { Industrial and } \\
\text { Organizational } \\
\text { Psychology (2011)". }\end{array}$ & $\begin{array}{l}\text { To explore } \\
\text { the } \\
\text { relationship } \\
\text { between } \\
\text { employees' } \\
\text { job } \\
\text { satisfaction } \\
\text { and } \\
\text { organization } \\
\text { al } \\
\text { commitment }\end{array}$ & IT/South Africa & $\begin{array}{l}\text { job } \\
\text { satisfaction, } \\
\text { organizational } \\
\text { commitment, } \\
\text { affective } \\
\text { commitment, } \\
\text { normative } \\
\text { commitment, } \\
\text { continuance } \\
\text { commitment. } \\
\text { (86). }\end{array}$ & $\begin{array}{l}\text { The results suggest } \\
\text { that in order to } \\
\text { create a working } \\
\text { environment that } \\
\text { encourages people to } \\
\text { stay with their } \\
\text { respective } \\
\text { organization'smanag } \\
\text { ers need to review } \\
\text { existing pay } \\
\text { practices so as to } \\
\text { offer fair } \\
\text { pay, provide } \\
\text { challenging and } \\
\text { meaningful work } \\
\text { tasks, and foster } \\
\text { positive co-worker } \\
\text { relationships. }\end{array}$ \\
\hline $\begin{array}{l}\text { "Employee Fairness } \\
\text { Perceptions ofa } \\
\text { Performance } \\
\text { Management System, } \\
\text { Master Thesis in } \\
\text { Industrial } \\
\text { andOrganizational } \\
\text { Psychology, University } \\
\text { of South Africa. } \\
\text { ManokoMagdelineMatl } \\
\text { ala (2011)". }\end{array}$ & $\begin{array}{l}\text { This study } \\
\text { deals with } \\
\text { the employee } \\
\text { fairness } \\
\text { perceptions } \\
\text { of their } \\
\text { performance } \\
\text { management } \\
\text { system in a } \\
\text { South } \\
\text { African } \\
\text { organization. }\end{array}$ & $\begin{array}{l}\text { Organization/South } \\
\text { Africa }\end{array}$ & $\begin{array}{l}\text { Performance; } \\
\text { Performance } \\
\text { management; } \\
\text { Organizationa } \\
l \quad \text { justice; } \\
\text { Distributive } \\
\text { justice; } \\
\text { Procedural } \\
\text { justice; } \\
\text { Interactional } \\
\text { justice; } \\
\text { Employee } \\
\text { perceptions; }\end{array}$ & $\begin{array}{l}\text { The overall } \\
\text { findings show that } \\
\text { there are negative } \\
\text { fairness perceptions } \\
\text { of the performance } \\
\text { management } \\
\text { system as assessed } \\
\text { according to the } \\
\text { three organizational } \\
\text { justice factors of } \\
\text { procedural, } \\
\text { distributive } \\
\text { and interactional }\end{array}$ \\
\hline
\end{tabular}




\begin{tabular}{|c|c|c|c|c|}
\hline & & & Fairness. (20) & justice. \\
\hline $\begin{array}{l}\text { "Examining the } \\
\text { Mediating Effect of } \\
\text { Employee Engagement } \\
\text { on the Relationship } \\
\text { between Talent } \\
\text { Management Practices } \\
\text { and Employee } \\
\text { Retention in the } \\
\text { Information and } \\
\text { Technology (IT) } \\
\text { Organizations } \\
\text { in Malaysia Journal of } \\
\text { Human Resources } \\
\text { Management and } \\
\text { Labor Studies June } \\
\text { 2014, Vol. 2, No. 2, pp. } \\
\text { 227-242. NurulEzaili } \\
\text { Alias1, NorzanahMohd } \\
\text { Noor2 and Roshidi } \\
\text { Hassan (2014)". }\end{array}$ & $\begin{array}{l}\text { seeks to } \\
\text { determine the } \\
\text { relationships } \\
\text { between } \\
\text { talent } \\
\text { management } \\
\text { practices } \\
\text { (managerial } \\
\text { support, } \\
\text { employee } \\
\text { career } \\
\text { development } \\
\text { and rewards } \\
\text { and } \\
\text { recognitions) } \\
\quad \text { employee } \\
\text { engagement } \\
\text { and employee } \\
\text { retention } \\
\text { within IT } \\
\text { organization } \\
\text { s in } \\
\text { Malaysia. }\end{array}$ & IT/Malaysia & $\begin{array}{l}\text { Talent } \\
\text { Management } \\
\text { Practices, } \\
\text { Employee } \\
\text { Engagement, } \\
\text { Employee } \\
\text { Retention, IT } \\
\text { organizations, } \\
\text { Turnover } \\
\text { (581). }\end{array}$ & $\begin{array}{l}\text { talent } \\
\text { management } \\
\text { practices } \\
\text { (managerial support, } \\
\text { employee career } \\
\text { development and } \\
\text { rewards and } \\
\text { recognitions) have } \\
\text { positive correlation } \\
\text { with employee } \\
\text { engagement. }\end{array}$ \\
\hline $\begin{array}{l}\text { "Relationship Between } \\
\text { Intrinsic Rewards and } \\
\text { Job Satisfaction: A } \\
\text { Comparative Study of } \\
\text { Public and Private } \\
\text { Organization, } \\
\text { International Journal } \\
\text { of Research in } \\
\text { Commerce, IT \& } \\
\text { Management Volume } \\
\text { No. } 2 \text { Issue No. } 6 \\
\text { (June). Tausif M. } \\
\text { (2012)". }\end{array}$ & $\begin{array}{l}\text { explore the } \\
\text { relationship } \\
\text { between } \\
\text { intrinsic } \\
\text { rewards and } \\
\text { job } \\
\text { satisfaction } \\
\text { for } \\
\text { employees of } \\
\text { service } \\
\text { sector. }\end{array}$ & $\begin{array}{l}\text { Service } \\
\text { Sector/Pakistan }\end{array}$ & $\begin{array}{l}\text { Job } \\
\text { satisfaction, } \\
\text { Intrinsic } \\
\text { Rewards, } \\
\text { Banking } \\
\text { sector, } \\
\text { Recognition, } \\
\text { Task } \\
\text { Autonomy. } \\
\text { (384). }\end{array}$ & $\begin{array}{l}\text { suggest the intrinsic } \\
\text { rewards such as task } \\
\text { autonomy, task } \\
\text { significance, task } \\
\text { involvement, } \\
\text { Opportunities to } \\
\text { learn new things and } \\
\text { recognition are } \\
\text { important } \\
\text { antecedence to job } \\
\text { satisfaction for the } \\
\text { employees of service } \\
\text { sector organizations. }\end{array}$ \\
\hline $\begin{array}{l}\text { "The Impact of Reward } \\
\text { and Recognition } \\
\text { Programs On } \\
\text { Employee's Motivation } \\
\text { and Satisfaction: An } \\
\text { Empirical Study } \\
\text { International Review of } \\
\text { Business Research } \\
\text { Papers } \\
\text { Vol. } 5 \text { No. } 4 \text { June } 2009 \\
\text { Pp.270-279, Reena Ali1 } \\
\text { and M. Shakil Ahmed } \\
\text { (2009)". }\end{array}$ & $\begin{array}{l}\text { The impact } \\
\text { of reward } \\
\text { and } \\
\text { recognition } \\
\text { programs on } \\
\text { employee's } \\
\text { motivation } \\
\text { and } \\
\text { satisfaction }\end{array}$ & Manufacturing & $\begin{array}{l}\text { HRM, } \\
\text { Motivation, } \\
\text { Satisfaction } \\
(80) \text {. }\end{array}$ & $\begin{array}{l}\text { The study revealed } \\
\text { that if rewards or } \\
\text { recognition offered } \\
\text { to } \\
\text { employees were to be } \\
\text { altered, then there } \\
\text { would be a } \\
\text { corresponding } \\
\text { change in } \\
\text { work motivation and } \\
\text { satisfaction. }\end{array}$ \\
\hline
\end{tabular}

